\title{
Clostridium sardiniense Prévot 1938 and Clostridium absonum Nakamura et al. 1973 are heterotypic synonyms: evidence from phylogenetic analyses of phospholipase $\mathrm{C}$ and $16 \mathrm{~S}$ rRNA sequences, and DNA relatedness
}

\begin{abstract}
Correspondence
Tadahiro Karasawa karasawa@mhs.mp. kanazawa-u.ac.jp
\end{abstract}

\section{Xingmin Wang, † Tsuneo Maegawa,ł Tadahiro Karasawa,§ Eijiro Ozaki and Shinichi Nakamura}

\begin{abstract}
Department of Bacteriology, Graduate School of Medical Science, Kanazawa University, 13-1 Takara-machi, Kanazawa 920-8640, Japan
\end{abstract}

\begin{abstract}
Clostridium sardiniense Prévot 1938 and Clostridium absonum Nakamura et al. 1973 have long been considered similar in terms of their biological and biochemical properties, but their taxonomic positions have not been clarified by DNA-DNA hybridization studies or rigorous analysis of $16 \mathrm{~S}$ rRNA genes. In the present study, DNA-DNA hybridization analysis revealed that C. absonum strains DSM 599 ${ }^{\top}$, DSM 600 and KZ 1544 shared 83.0-86.3\% DNA relatedness with $C$. sardiniense DSM $2632^{\top}$. $16 \mathrm{~S}$ rRNA gene sequence analysis showed that the C. absonum strains also shared high identity with C. sardiniense DSM $2632^{\top}(99 \cdot 7,99 \cdot 3$ and $99 \cdot 8 \%$ for DSM 599 ${ }^{\top}$, DSM 600 and KZ 1544, respectively), implying that C. absonum and C. sardiniense are synonyms. In addition, alignment of the inferred amino acid sequences for phospholipase C (PLC) indicated 96.5\% identity between PLCs from C. sardiniense and C. absonum, but relatively low identity with other clostridial species. These results strongly suggest that the species $C$. sardiniense and C. absonum should be united, with the name C. sardiniense having priority.
\end{abstract}

Clostridia produce lecithinases known as phospholipase C (PLC) (Titball, 1999; Jepson \& Titball, 2000). The best characterized clostridial PLC is produced by Clostridium perfringens. Because $C$. perfringens PLC is toxic to mammals, it is termed an alpha-toxin and considered a major virulence

Published online ahead of print on 4 January 2005 as DOI 10.1099/ ijs.0.63271-0.

†Present address: Department of Medicine, Infectious Diseases Section, University of Oklahoma Health Sciences Center, Oklahoma City, OK 73190, USA.

łPresent address: JCS Inc., 5-758 Nakamozu-cho, Sakai 591-8023, Japan.

§Present address: Department of Laboratory Sciences, School of Health Sciences, Kanazawa University, 5-11-80 Kodatsuno, Kanazawa 920-0942, Japan.

Abbreviation: PLC, phospholipase C.

The GenBank/EMBL/DDBJ accession numbers for the sequence of the gene encoding phospholipase C of C. sardiniense DSM $2632^{\top}$ and for the 16S rRNA gene sequences of C. sardiniense DSM $2632^{\top}$ and C. absonum (DSM 599 ${ }^{\top}$, DSM 600 and KZ 1544) are AB162962, $A B 161367-A B 161368$ and AB161369-AB161374, respectively.

Results of DNA-DNA hybridizations are available as supplementary material in IJSEM Online. factor. However, there are still many PLCs expressed by other clostridial species. Previous results suggest that these PLCs are similar but retain species-specific structure and function (Clark et al., 2003; Karasawa et al., 2003). Clostridium absonum was first described by Nakamura et al. (1973) and, unlike C. perfringens, is primarily isolated from soil and animal faeces. Later, this species was also identified as a causative agent of gas gangrene (Nakamura et al., 1979; Masaki et al., 1988). Although the morphological and biochemical properties of C. absonum are similar to those of C. perfringens (Nakamura et al., 1973; Hayase et al., 1974), C. absonum is easily differentiated from $C$. perfringens by the lecithinase (PLC) neutralization test. In this assay, PLC produced by $C$. absonum on half-antitoxin egg-yolk agar cannot be completely neutralized by $C$. perfringens type A antitoxin as is the C. perfringens PLC (Nakamura et al., 1973). Recently, our research group isolated the PLC gene (caa) from C. absonum and characterized the crystal structure of the expressed protein (Caa) (Clark et al., 2003). In the course of these studies, particular attention was paid to Clostridium sardiniense since this species is similar to C. absonum in biological and biochemical properties (Cato et al., 1986). C. sardiniense was initially described by Prévot in 1938 as a PLC-producing clostridial species. It is 
frequently isolated from soil samples (Rodriguez et al., 1993) and the faeces of infants (Borriello, 1980), although no association with gas gangrene has been reported. We isolated the PLC gene from C. sardiniense and found it to be highly homologous to $\mathrm{caa}$, suggesting both genes may derive from the same species. Based on 16S rRNA gene sequence data, C. sardiniense has been classified relatively far from $C$. absonum in Clostridium 16S rRNA Cluster I (Collins et al., 1994). However, no DNA-DNA hybridization studies have been performed to confirm this phylogenetic relationship. Therefore, to clarify the taxonomic relationship between three strains of C. absonum (DSM 599 $9^{\mathrm{T}}$, DSM 600 and KZ 1544) and C. sardiniense DSM $2632^{\mathrm{T}}$, we compared inferred amino acids for the respective PLCs and 16S rRNA genes, and performed DNA-DNA hybridization analyses.

C. sardiniense DSM $2632^{\mathrm{T}}\left(=\right.$ ATCC $\left.33455^{\mathrm{T}}=\mathrm{VPI} 2971^{\mathrm{T}}\right)$, C. absonum DSM $599^{\mathrm{T}} \quad\left(=\right.$ ATCC $27555^{\mathrm{T}}=$ NCTC $\left.10984^{\mathrm{T}}=\mathrm{CIP} 104302^{\mathrm{T}}=\mathrm{JCM} 1381^{\mathrm{T}}\right)($ Clark et al., 2003), C. absonum DSM 600, C. absonum KZ 1544 (Nakamura et al., 1979), C. perfringens KZ 221 (Tsutsui et al., 1995; Karasawa et al., 2003), Clostridium bifermentans KZ 1012 (Karasawa et al., 2003) and Clostridium sordellii NCIMB $10717^{\mathrm{T}}$ ( = ATCC 9714 ${ }^{\mathrm{T}}$ ) (Karasawa et al., 2003) were used in this study. For extraction of whole-cell DNA, bacterial strains were cultured in $40 \mathrm{ml}$ of GAM broth (Nissui Pharmaceutical) at $37^{\circ} \mathrm{C}$ for $16 \mathrm{~h}$. Extraction and purification of whole-cell DNA was performed as described previously (Wang et al., 2000; Karasawa et al., 2003). As a preliminary experiment, a $900 \mathrm{bp}$ fragment of the plc gene of $C$. sardiniense was amplified by using the KAG209 (5'-TGGGATGGAAAAGATTGATGGAACAGG-3') and KAG210 (5'-TTTCTCTTTTCTTATCCACATATTCTTGTATATC- $3^{\prime}$ ) primer set for highly conserved regions of clostridial plc genes (Karasawa et al., 2003). The sequence of the $900 \mathrm{bp}$ fragment showed high identity with the $C$. absonum caa gene (Clark et al., 2003). Therefore, the whole open reading frame was amplified by using the KAG188 (5'-CCAACCACAATTATCTTCTTTACTACCT-3') and KAG201 (5'-CACATCCTGTTATCTCTTCCTATCA-3') primer set that encodes sequences flanking caa. The PCR mixture consisted of $0.2 \mathrm{mM}$ (each) deoxynucleotide triphosphates, $50 \mathrm{pmol}$ of each primer, $100 \mathrm{ng}$ of wholecell DNA and 2.5 units of TaKaRa Ex Taq (Takara Shuzo) in a $50 \mu \mathrm{l}$ of buffer. The PCR was performed as follows: pre-denaturation at $94^{\circ} \mathrm{C}$ for $1 \mathrm{~min}$, followed by 30 cycles at $94{ }^{\circ} \mathrm{C}$ for $20 \mathrm{~s}, 58^{\circ} \mathrm{C}$ for $15 \mathrm{~s}$ and $72{ }^{\circ} \mathrm{C}$ for $45 \mathrm{~s}$ on a GeneAmp PCR System 9700 (Applied Biosystems). PCR products were electrophoresed on a $1 \%$ agarose gel and a fragment of approximately $1300 \mathrm{bp}$ was extracted by using a QIAquick Gel Extraction kit (Qiagen). The purified fragment was ligated to a pCRII-TOPO TA cloning vector (Invitrogen) and transformed into competent Escherichia coli TOP $10 \mathrm{~F}^{\prime}$ cells according to the manufacturer's instructions. Transformants were screened on a $2 \times$ YT plate containing $50 \mu \mathrm{g}$ ampicillin $\mathrm{ml}^{-1}$ and $5 \%$ egg yolk. Several colonies were identified that showed the characteristic lecithinase reaction of opacity around a colony. The plasmid of a PLC-positive transformant was extracted with a QIAprep Spin Miniprep kit (Qiagen), sequenced in both directions using a BigDye ${ }^{\mathrm{TM}}$ Terminator Cycle Sequencing Ready Reaction kit (Applied Biosystems) with synthetic primers and electrophoresed on an ABI Prism 310 Genetic Analyser (Applied Biosystems). A 1519 bp fragment of the 16S rRNA gene was amplified by using KAG268 (5' ${ }^{\prime}$-TTTAAATTGAGAGTTTGATCCTGGCTCA-3') and KAG269 (5' -AGAAAGGAGGTGATCCAGCCGCA-3') as a primer set, designed from conserved sequences identified by comparing several clostridial $16 \mathrm{~S}$ rRNA genes. The amplification, cloning and sequencing of the 16S rRNA genes were the same as described for the C. sardiniense plc gene except PCR was carried out using a two-step procedure of 30 cycles at $94^{\circ} \mathrm{C}$ for $20 \mathrm{~s}$ and $72^{\circ} \mathrm{C}$ for $40 \mathrm{~s}$, after pre-heating at $94^{\circ} \mathrm{C}$ for $1 \mathrm{~min}$. To prepare DNA probes for DNA-DNA hybridization analysis, chromosomal DNA was labelled by random priming using digoxigenindUTP according to the manufacturer's instructions for the DIG High Prime DNA Labelling and Detection Starter Kit II (Roche Molecular Biochemicals). DNA-DNA hybridization was carried out as described by Ezaki et al. (1989) with some modifications. Purified chromosomal DNA was diluted to $100 \mu \mathrm{g} \mathrm{ml}^{-1}$ with $\mathrm{H}_{2} \mathrm{O}$ and denatured by boiling for $10 \mathrm{~min}$ at $100^{\circ} \mathrm{C}$. Denatured DNA was diluted to $20 \mu \mathrm{g} \mathrm{ml}^{-1}$ with PBS $\left(8 \mathrm{mM} \mathrm{Na} \mathrm{NaPO}_{4}, 1.5 \mathrm{mM}\right.$ $\left.\mathrm{KH}_{2} \mathrm{PO}_{4}, \mathrm{pH} 7 \cdot 2,137 \mathrm{mM} \mathrm{NaCl}, 2 \cdot 7 \mathrm{mM} \mathrm{KCl}\right)$ containing $0 \cdot 1 \mathrm{M} \mathrm{MgCl}$, and aliquots $(100 \mu \mathrm{l})$ were immobilized onto NUNC-immuno microplates (Nalge Nunc International) by incubation at $37^{\circ} \mathrm{C}$ for $3 \mathrm{~h}$. Duplicate controls were made for each DNA sample. After aspirating the coating solution, $200 \mu$ lof pre-hybridization solution $[2 \times$ SSC $(1 \times$ SSC is $0 \cdot 15 \mathrm{M} \mathrm{NaCl} / 0 \cdot 015 \mathrm{M}$ sodium citrate $), 5 \times$ Denhardt's solution, $25 \%$ formamide, $200 \mu \mathrm{g}$ salmon sperm DNA ml ${ }^{-1}$ ] was added to wells and incubated at $37^{\circ} \mathrm{C}$ for $3 \mathrm{~h}$. Before hybridization with labelled DNA probe, wells were washed three times with $2 \times$ SSC. Onehundred microlitres of hybridization solution $(2 \times$ SSC, $5 \times$ Denhardt's solution, 3\% dextran sulfate, $25 \%$ formamide, $50 \mu \mathrm{g}$ denatured salmon sperm DNA ml ${ }^{-1}, 0 \cdot 5 \mu \mathrm{g}$ denatured digoxigenin-dUTP labelled probe $\mathrm{ml}^{-1}$ ) was added to wells and incubated at $37^{\circ} \mathrm{C}$ overnight. The wells were washed three times with $300 \mu \mathrm{l}$ of $2 \times$ SSC and once with $300 \mu \mathrm{l}$ of washing buffer $(0 \cdot 1 \mathrm{M}$ maleic acid, $0 \cdot 15 \mathrm{M}$ $\mathrm{NaCl}, \mathrm{pH} 7 \cdot 5,0 \cdot 3 \%$ Tween 20 ). Detection of dsDNA was done by using an anti-digoxigenin-alkaline phosphatase conjugate included in the kit. Finally, $100 \mu \mathrm{l}$ of $p$ nitrophenyl phosphate disodium $\left(\mathrm{mg} \mathrm{ml}^{-1}\right.$ ) (in $0.05 \mathrm{M}$ Tris/HCl, pH $10 \cdot 0,0 \cdot 1 \mathrm{M} \mathrm{NaCl}, 0.5 \mathrm{mM} \mathrm{MgCl}_{2}$ ) was dispensed into the wells, with a $30 \mathrm{~min}$ incubation at $37^{\circ} \mathrm{C}$, and the reaction was stopped by adding $100 \mu \mathrm{l}$ of $3 \mathrm{M}$ $\mathrm{NaOH}$. Absorbance was measured with a microplate reader EAR 340 AT (Tecan) at $405 \mathrm{~nm}$ with a reference wavelength of $620 \mathrm{~nm}$. The assay was repeated at least three times for all strains with results shown as the mean \pm SD. Multiple alignments of sequences were created by using the CLUSTAL $\mathrm{W}$ method and phylogenetic trees were calculated by using the neighbour-joining method 


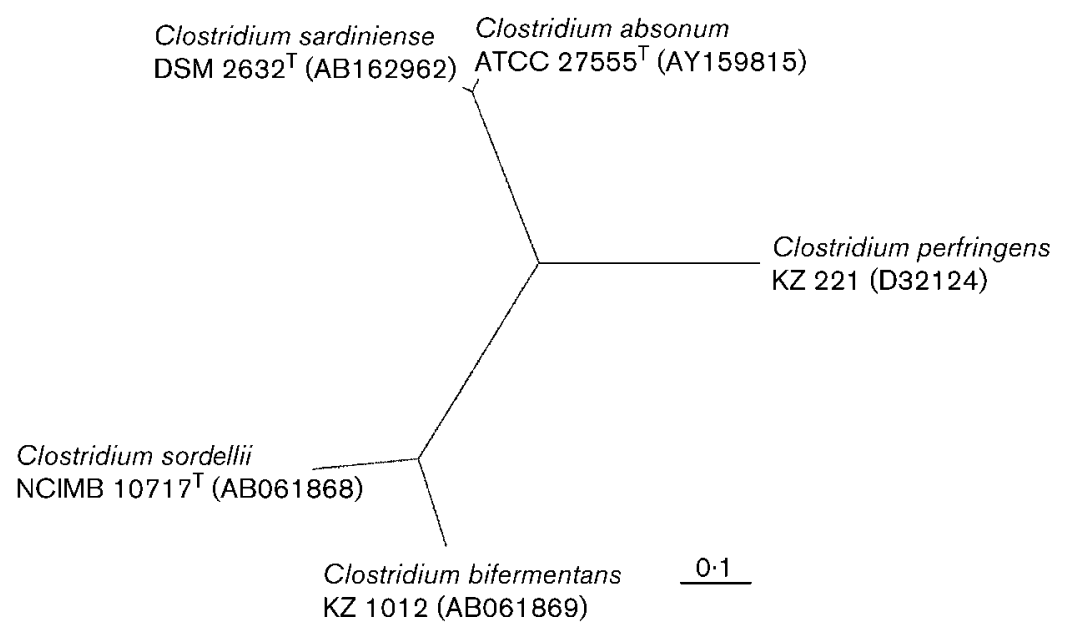

Fig. 1. Unrooted phylogenetic tree based on PLC amino acid sequences. Bar, $0 \cdot 1$ substitution per site.

contained within an online software package (http://www. ddbj.nig.ac.jp/search/clustalw-e.html). Unrooted phylogenetic trees were constructed with TreeView (version 1.6.6 for Windows) software.

The plc gene of C. sardiniense DSM $2632^{\mathrm{T}}$ consisted of $1197 \mathrm{nt}$ encoding 398 aa residues. The inferred protein had a molecular mass of $45 \cdot 7 \mathrm{kDa}$ and a pI of $5 \cdot 26$. Between the plc gene of $C$. sardiniense and the caa gene of C. absonum DSM 599 ${ }^{\mathrm{T}}$ (Clark et al., 2003), nucleotide differences were found at 57 positions, resulting in coding changes for 14 aa. Alignment of amino acid sequences revealed that the $C$. sardiniense PLC had 96.5\% identity with Caa and showed relatively low identity with PLCs from C. perfringens (Cpa), C. bifermentans (Cbp) and $C$. sordellii (Csp) (Karasawa et al., 2003). A phylogenetic tree based on the amino acid sequences of PLCs from related clostridial species is shown in Fig. 1. The PLC of C. sardiniense was closely related to that of C. absonum. Not surprisingly, since $C$. bifermentans and $C$. sordellii are classified in the same Clostridium 16S rRNA cluster XI by Collins et al. (1994), Cbp appeared closely related to Csp.
Cbp and Csp, however, were only loosely related to Cpa, Caa and the $C$. sardiniense PLC.

As mentioned above, Caa could not be completely neutralized with antiserum to Cpa (Nakamura et al., 1973). When the half-antitoxin egg-yolk agar test (Willis \& Hobbs, 1958) was used to compare PLCs of C. sardiniense and C. absonum, the C. sardiniense DSM $2632^{\mathrm{T}}$ PLC was also incompletely neutralized by antiserum to $C$. perfringens PLC (data not shown).

The 16S rRNA genes from C. sardiniense DSM $2632^{\mathrm{T}}$ and C. absonum DSM 599 ${ }^{\mathrm{T}}$, DSM 600 and KZ 1544 were sequenced. Alignment of the $16 \mathrm{~S}$ rRNA gene sequences revealed that the $C$. absonum strains shared extremely high identity with the sequence of C. sardiniense DSM $2632^{\mathrm{T}}$ (99.3-99.9\%). A phylogenetic tree based on 16S rRNA gene sequences is shown in Fig. 2. C. absonum strains DSM 599 ${ }^{\mathrm{T}}$, DSM 600 and KZ 1544 appeared closely related to C. sardiniense DSM $2632^{\mathrm{T}}$. According to Collins et al. (1994), although C. sardiniense, as well as C. absonum, is classified in Clostridium 16S rRNA cluster I, C. sardiniense is only loosely associated with C. absonum. Of note is that

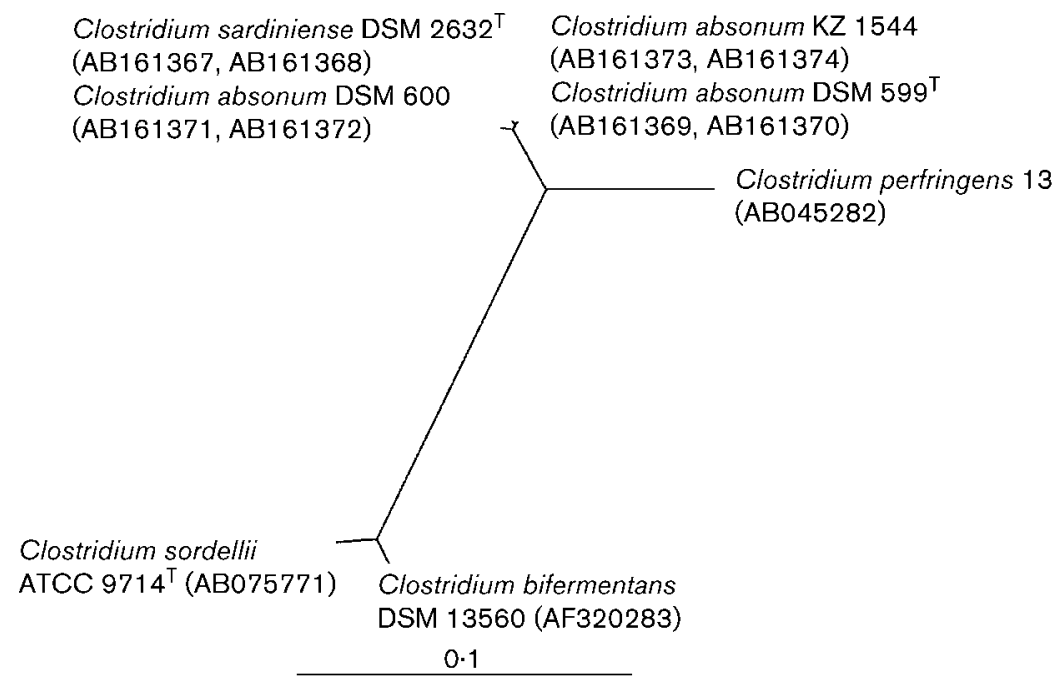

Fig. 2. Unrooted phylogenetic tree based on 16S rRNA gene sequences. Bar, 0.1 substitution per site. The microheterogeneity of the 16S rRNA gene from C. absonum and $C$. sardiniense strains did not affect the phylogenetic tree. 
the 16S rRNA gene sequences for both $C$. absonum and C. sardiniense in GenBank/EMBL/DDBJ (accession nos X77842 and X73446, respectively) contain several undetermined nucleotide residues, probably resulting in the loose association reported by Collins et al. (1994). Indeed, we also found a few undetermined nucleotide residues in preliminary sequences for these 16S rRNA genes when we used a direct method with PCR products. Therefore, the PCR products of the $16 \mathrm{~S}$ rRNA genes were cloned into a plasmid vector and three to six clones were sequenced per strain. Our results indicated two kinds of $16 \mathrm{~S}$ rRNA gene with microheterogeneity in every strain tested. The two different clones found in C. sardiniense DSM $2632^{\mathrm{T}}$ were defined as DSM $2632^{\mathrm{C} 1}$ (four of six sequenced clones) and DSM $2632^{\mathrm{C} 2}$ (two of six sequenced clones). Differences found at six nucleotide positions between DSM $2632^{\mathrm{Cl}}$ and DSM $2632^{\mathrm{C} 2}$ were: G819, C880, C1001, T1003, G1010 and G1489 in DSM $2632^{\mathrm{C} 1}$ substituted by A819, T880, T1001, C1003, A1010 and A1489 in DSM $2632^{\mathrm{C} 2}$. Microheterogeneities were also found in three strains of C. absonum with C1001 and G1010 in DSM $599^{\mathrm{Cl}}$ (two of three clones) substituted by $\mathrm{T} 1001$ and A1010 in DSM $599^{\mathrm{C} 2}$ (one of three clones); C225, C359, C442, A819, C821 and C982 in DSM 600 ${ }^{\mathrm{C} 1}$ (two of three clones) substituted by T225, T359, T442, G819, T821 and T982 in DSM $600^{\mathrm{C} 2}$ (two of three clones); and T1001, T1003 and G1010 in KZ $1544^{\mathrm{C} 1}$ (two of three clones) substituted by C1001, C1003 and A1010 in KZ $1544^{\mathrm{C} 2}$ (one of three clones). Microheterogeneities have been reported in the $16 \mathrm{~S} r r n$ operon of E. coli (Carbon et al., 1979), the $23 \mathrm{Srn}$ operon of Clostridium botulinum type A (East et al., 1992) and the 5S rrn operon of Bacillus species (Raue et al., 1977). Although microheterogeneity does not pose a problem for phylogenetically distant organisms, such considerations become increasingly important when close genealogical relationships exist (East et al., 1992). However, despite the microheterogeneity, the phylogenetic analysis of $16 \mathrm{~S}$ rRNA gene sequences implies that C. absonum and C. sardiniense can be classified at equal taxonomic positions.

High levels of DNA relatedness were detected between $C$. sardiniense DSM $2632^{\mathrm{T}}$ and the three strains of C. absonum: $\left(83 \cdot 0,84 \cdot 7\right.$ and $86 \cdot 3 \%$ for DSM $599^{\mathrm{T}}$, DSM 600 and $\mathrm{KZ}$ 1544, respectively) (results of DNA-DNA hybridizations are available as supplementary material in IJSEM Online). However, relatively low levels of DNA relatedness $(18 \cdot 2-$ $28.0 \%$ ) were detected between C. perfringens KZ 221 and all strains of $C$. absonum and C. sardiniense. A relatively high level of DNA relatedness $(64 \cdot 6 \%)$ was found for $C$. bifermentans and C. sordellii, which are considered closely related based on data from 16S rRNA gene sequences (Collins et al., 1994) and DNA-DNA hybridization analyses (Nakamura et al., 1975). However, C. bifermentans and C. sordellii showed low level DNA relatedness to C. absonum, C. sardiniense and C. perfringens. DNA-DNA hybridization also indicated that C. absonum is equal to C. sardiniense in its phylogenetic position.
Interestingly, phylogenetic trees exhibited excellent correlation whether based on the inferred amino acid sequences of PLCs, 16S rRNA genes or degree of DNA relatedness in hybridization experiments. Our results suggest that the evolution of PLC closely parallels that of 16S RNA genes in PLC-producing clostridia. Genes encoding PLC could be as useful for phylogenetic analysis of PLC-producing clostridia as $16 \mathrm{~S}$ rRNA genes. Similarly, the phylogenetic tree based on $16 \mathrm{~S}$ rRNA gene sequences of PLC-producing clostridia should provide good clues for analysing the primary structure and function of clostridial PLCs.

C. sardiniense and C. absonum were first described by Prévot (1938) and Nakamura et al. (1973), respectively. Cato et al. (1986) recognized that C. sardiniense was similar to C. absonum in its biological and biochemical properties, and further noted that ' $C$. sardiniense is differentiated from C. absonum by motility but since some strains labeled $C$. absonum have been found to be motile, clear separation of the species must await DNA homology studies'. However, until this study, the taxonomic position of both species had not been clarified. DNA hybridization studies had not been conducted, and the 16S rRNA gene sequences for C. absonum DSM $599^{\mathrm{T}}$ and C. sardiniense DSM $2632^{\mathrm{T}}$ in GenBank/EMBL/DDBJ (accession nos X77842 and X73446, respectively) contained undetermined nucleotides, resulting in a reportedly loose association between these species (Collins et al., 1994). The present study has demonstrated that C. absonum strains DSM 599 ${ }^{\mathrm{T}}$, DSM 600 and KZ 1544 share $83 \cdot 0-86 \cdot 3 \%$ DNA relatedness with $C$. sardiniense strain DSM $2632^{\mathrm{T}}$. Moreover, 16S rRNA gene sequence analysis showed that all C. absonum strains in this study shared high identity with C. sardiniense DSM $2632^{\mathrm{T}}(99 \cdot 7$, $99 \cdot 3$ and $99 \cdot 8 \%$ for DSM $599^{\mathrm{T}}$, DSM 600 and KZ 1544, respectively), implying that $C$. absonum and $C$. sardiniense can now be classified at equal taxonomic positions. In addition, alignment of inferred amino acids for PLCs indicated $96.5 \%$ identity between the $C$. sardiniense and C. absonum proteins, but relatively low identity to other clostridial species. These results strongly suggest that the names $C$. sardiniense and C. absonum are synonyms. Therefore, according to Rule $24 \mathrm{~b}$ of the International Code of Nomenclature of Bacteria, we propose that $C$. absonum be recognized as a later synonym of $C$. sardiniense, and that the species $C$. sardiniense and $C$. absonum should be united, with the name $C$. sardiniense having priority.

\section{Emended description of Clostridium sardiniense Prévot 1938}

Later heterotypic synonym: Clostridium absonum Nakamura et al. 1973 (Approved Lists 1980).

The description of the species is as given by Cato et al. (1986), based mainly on the studies of Nakamura et al. (1973) and Holdeman et al. (1977).

The type strain is DSM $2632^{\mathrm{T}}\left(=\mathrm{ATCC} 33455^{\mathrm{T}}=\mathrm{VPI}\right.$ $\left.2971^{\mathrm{T}}\right)$. 


\section{Acknowledgements}

This work was supported in part by grants-in-aid from the JapanChina Medical Association and from Yakult Honsha Co., Ltd. We would like to thank Dr Y. Kawamura (Microbiology-Bioinformatics, Regeneration and Advanced Medical Science, Gifu University Graduate School of Medicine, Gifu, Japan) for his helpful discussion and Dr M. Huycke (Department of Medicine, Infectious Diseases Section, University of Oklahoma Health Sciences Center, Oklahoma City, OK, USA) for reviewing the manuscript.

\section{References}

Borriello, S. P. (1980). Clostridial flora of the gastrointestinal tract in health and disease. $\mathrm{PhD}$ thesis, University of London.

Carbon, P., Ehresmann, C., Ehresmann, B. \& Ebel, J.-P. (1979). The complete nucleotide sequence of the ribosomal 16-S RNA from Escherichia coli. Experimental details and cistron heterogeneities. Eur J Biochem 100, 399-410.

Cato, E. P., Georgy, W. L. \& Finegold, S. M. (1986). Genus Clostridium Prazmowski 1880, 23 ${ }^{\mathrm{AL}}$. In Bergey's Manual of Systematic Bacteriology, vol. 2, pp. 1141-1200. Edited by P. H. A. Sneath, N. S. Mair, M. E. Sharpe \& J. G. Holt. Baltimore: Williams \& Wilkins.

Clark, G. C., Briggs, D. C., Karasawa, T. \& 10 other authors (2003). Clostridium absonum alpha-toxin: new insights into clostridial phospholipase C substrate binding and specificity. J Mol Biol 333, 759-769.

Collins, M. D., Lawson, P. A., Willems, A., Cordoba, J. J., FernandezGarayzabal, J., Garcia, P., Cai, J., Hippe, H. \& Farrow, J. A. (1994). The phylogeny of the genus Clostridium: proposal of five new genera and eleven new species combinations. Int J Syst Bacteriol 44, 812-826.

East, A. K., Thompson, D. E. \& Collins, M. D. (1992). Analysis of operons encoding 23S rRNA of Clostridium botulinum type A. $J$ Bacteriol 174, 8158-8162.

Ezaki, T., Hashimoto, Y. \& Yabuuchi, E. (1989). Fluorometric deoxyribonucleic acid-deoxyribonucleic acid hybridization in microdilution wells as an alternative to membrane filter hybridization in which radioisotopes are used to determine genetic relatedness among bacterial strains. Int J Syst Bacteriol 39, 224-229.

Hayase, M., Mitsui, N., Tamai, K., Nakamura, S. \& Nishida, S. (1974). Isolation of Clostridium absonum and its cultural and biochemical properties. Infect Immun 9, 15-19.

Holdeman, L. V., Cato, E. P. \& Moore, W. E. C. (1977). Anaerobe Laboratory Manual, 4th edn. Blacksburg, VA: Anaerobe Laboratory, Virginia Polytechnic Institute and State University.
Jepson, M. \& Titball, R. W. (2000). Structure and function of clostridial phospholipases C. Microbes Infect 2, 1277-1284.

Karasawa, T., Wang, X., Maegawa, T., Michiwa, Y., Kita, H., Miwa, K. \& Nakamura, S. (2003). Clostridium sordellii phospholipase C: gene cloning and comparison of enzymatic and biological activities with those of Clostridium perfringens and Clostridium bifermentans phospholipase C. Infect Immun 71, 641-646.

Masaki, T., Umehashi, H., Miyazaki, H., Takano, M., Yamakawa, K. \& Nakamura, S. (1988). Clostridium absonum from gas gangrene. Jpn J Med Sci Biol 41, 27-30.

Nakamura, S., Shimamura, T., Hayase, M. \& Nishida, S. (1973). Numerical taxonomy of saccharolytic clostridia, particularly Clostridium perfringens-like strains: descriptions of Clostridium absonum sp. n. and Clostridium paraperfringens. Int J Syst Bacteriol 23, 419-429.

Nakamura, S., Shimamura, T., Hayashi, H. \& Nishida, S. (1975). Reinvestigation of the taxonomy of Clostridium bifermentans and Clostridium sordellii. J Med Microbiol 8, 299-309.

Nakamura, S., Yamakawa, K., Hashimoto, H. \& Nishida, S. (1979). Isolation of Clostridium absonum from a case of gas gangrene. Microbiol Immunol 23, 685-687.

Prévot, A. R. (1938). Études de systématique bactérienne. IV. Critique de la conception actuelle du genre Clostridium. Ann Inst Pasteur (Paris) 61, 72-91 (in French).

Raue, H. A., Rosner, A. \& Planta, R. J. (1977). Heterogeneity of the genes coding for 5S RNA in three related strains of the genus Bacillus. Mol Gen Genet 156, 185-193.

Rodriguez, E., Mar Gamboa, M. D. \& Fernandez, B. (1993). Mesophilic clostridia from soil of the central plateau of Costa Rica. Rev Biol Trop 41, 365-369 (in Spanish).

Titball, R. W. (1999). Membrane-damaging and cytotoxic phospholipases. In The Comprehensive Sourcebook of Bacterial Protein Toxins, 2nd edn, pp. 310-329. Edited by J. E. Alouf \& J. H. Freer. London: Academic Press.

Tsutsui, K., Minami, J., Matsushita, O., Katayama, S., Taniguchi, Y., Nakamura, S., Nishioka, M. \& Okabe, A. (1995). Phylogenetic analysis of phospholipase $\mathrm{C}$ genes from Clostridium perfringens types A to E and Clostridium novyi. J Bacteriol 177, 7164-7170.

Wang, X., Maegawa, T., Karasawa, T. \& 7 other authors (2000). Genetic analysis of type E botulinum toxin-producing Clostridium butyricum strains. Appl Environ Microbiol 66, 4992-4997.

Willis, A. T. \& Hobbs, G. (1958). A medium for the identification of clostridia producing opalescence in egg-yolk emulsion. I Pathol Bacteriol 75, 299-305. 